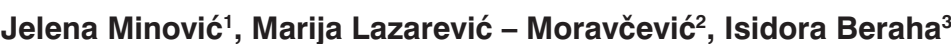
${ }^{2}$ Belgrade Banking Academy, Faculty for banking, insurance and finance, Union University ${ }_{1,3}$ Institute of Economic Sciences, Zmaj Jovina 12, Belgrade

UDC: 005.521:334.7(497.11) 005.21

\title{
Strategic Orientation of SMEs: Empirical Research
}

DOI: 10.7595/management.fon.2016.0026

The main objective of the paper is to identify the sources of competitive advantage of small and medium-sized enterprises in Serbia. Gaining a competitive advantage is the key priority of market-oriented enterprises regardless of their size and sector. Since business environment in Serbia is not stimulating enough for enterprises' growth and development, the paper highlights the role of strategic orientation in business promotion and development. In order to identify the sources of competitive advantage, the empirical research is conducted by using the survey method. The research sample is created by using a selective approach, namely, the sample includes enterprises with more than ten employees, and enterprises identified to have the potential for growth and development. The research results indicate that small and medium-sized enterprises in Serbia are generally focused on costs as a source of competitive advantage, i.e., they gain competitive advantage in a selected market segment by offering low price and average quality products/services. In addition, the results of the research point out that the Serbian small and medium-sized enterprises are innovation-oriented. Organizations qualifying as middle-sized enterprises are predominantly focused on process innovations, while small businesses are primarily oriented towards product innovations. One of the limitations of the research refers to the small presence of the research sample within the category of middle-sized enterprises. The smaller sample presence than it was previously planned is mostly due to the lack of managers' willingness to participate in the research, as well as to the fact that these enterprises account for the smaller share in the total number of enterprises in the small-and medium-sized enterprises' sector. Taking into account that the sector of small and medium-sized enterprises generates around $30 \%$ of the country's GDP, we consider the research results to be beneficial for both scientific and professional communities, as well as for economic policy makers in Serbia.

Keywords: Strategic orientation, SME, competitive advantage, competitive strategies, costs, differentiation, innovation.

\section{Introduction}

Micro, small and medium-sized enterprises (SMEs) represent a significant economic force that contributes to income growth, new job creation, total turnover and export generation. In fact, the SME sector in Serbia accounts for $99.8 \%$ of all active enterprises, it contributes up to $2 / 3$ of employment in the non-financial sector of the economy and generates almost 30\% of Serbia's GDP (National Agency for Regional Development, 2013).

Despite the role that SMEs play in fostering economic growth and development, their operation in Serbia is constrained by numerous external factors. Business environment for SMEs in Serbia is still rather inconvenient. The key factors causing the uncertainty of the business environment refer to the inefficiency of state bureaucracy, limited access to financing and corruption (WEF, 2016). According to the Doing Business Report 2016, Serbia is ranked 59th out of a total of 189 countries in terms of the quality of business environment. In comparison with the previous year, Serbia has made progress by moving up 9 positions. Serbia's highest rank is in terms of international trade (23th), while its lowest ranking for many years now has been in terms of getting construction permits (139th) (World Bank, 2016). Stosic\&Minovic (2014) analysed the relative positions of the Western Balkan countries and determined the differences or similarities in the results based on the survey data (of international institutions: EBRD, World Bank, World Economic Forum, and Heritage Foundation). They empirically found that the relative position of a certain country in a region 
(in this case the Western Balkans) cannot be determined only by a single methodology and approach. This finding by Stosic\&Minovic (2014) is particularly important since estimations of the relative position and economic progress are often easily made solely on the basis of judgements of international institutions.

Considering the effects of the above mentioned, as well as many other factors from external environment that have a negative impact on growth and development of enterprises, this paper starts with the assumption that the key factors of business growth and development can be found in internal forces, and particularly in the area of management skills.

The subject of the paper is to analyse approaches, i.e., sources that small business systems in Serbia use to create competitive advantage. The empirical research was based on the assumption that due to certain specifics of the business environment, the choice of a competitive strategy for SMEs in Serbia is limited and implies the use of a focus strategy. The key research question is whether SMEs in selected markets are focused on costs or on differentiation.

The research started from the following hypotheses:

- SMEs in Serbia carry out innovative activities.

- The type of innovation carried out by an enterprise (product innovation or process innovation) is aligned with its competitive strategy.

The paper is structured as follows: the first chapter contains an introduction and motivation for research, the second section gives an overview of the literature relevant to the field of research, the third chapter describes the research methodology, the fourth section presents research results and discussion, while the fifth chapter brings conclusions to the paper.

\section{Literature Review}

Literature dealing with strategic orientation of SMEs in both developed and developing countries is very extensive. Gatignon\&Xuereb (1997) explored which of the three different strategic orientations (customer, competitive, and technological) is suitable for an enterprise. However, a significant number of research papers are related to commercial innovation and innovative performance, whereby some of them refer to the work of the following authors: Zhou et al. (2005), Verhees\&Meulenberg (2004), Lukas \& Ferrell (2000) Han et al. (1998), Hurley \&Hult (1998), Atuahene-Gima (1996), Greenley (1995), and others. The authors who put the focus of their research on the impact of knowledge and learning orientation upon firm innovativeness are Calantone et al. (2002), and Zack (1999). However, Keskin (2006) tested the combined effect of marketorientation and learning-orientation on firm innovativeness and performance in SMEs in Turkey. He has performed a questionnaire-based survey of managers from small-sized firms operating in Turkey, and received a total of 157 usable questionnaires from managers. The results of Keskin (2006) showed that firm innovativeness affected firm performance in a positive manner; firm learning-orientation positively influenced firm innovativeness; firm market-orientation positively impacted firm learning orientation; firm learningorientation mediated the relationship between firm market-orientation and firm innovativeness; and firm market-orientation indirectly impacted firm performance via firm innovativeness and learning.

Zhou et al. (2005) examined the effects of market and innovation orientations in transitional economies. Based on the survey of 2754 employees from 180 firms in China, they found that both market and innovation orientations strongly improve employees' attitude to job. Furthermore, these authors discussed implications of developing strategic orientations in transitional economies. The results of the model developed by Verhees\&Meulenberg (2004) that explores the existence of a combined effect of market orientation and innovativeness on product innovation indicate that the owner's innovativeness has a positive influence on market orientation, innovation, and performance. Additionally, Verhees\&Meulenberg (2004) identified that product innovation is affected by customer market intelligence either in a positive or a negative manner depending on the strength of the innovativeness of the owner in the new product domain. Lukas \& Ferrell (2000) investigated the relationship between market orientation and product innovation. They used a sample of U.S. manufacturing companies. Lukas \& Ferrell's (2000) results showed that product innovation varied with market orientation. Han et al. (1998) tested the following chain: market orientation-innovation-performance. These authors examined how the three core components of market orientation (customer orientation, 
competitor orientation, and inter-functional coordination) affected the two core components of organizational innovativeness (technical versus administrative) on route to affecting corporate performance. Han et al. (1998) used banking industry data, and they showed that in the banking industry, a service sector, administrative innovation may assume a relatively equal importance to its technical counterpart in influencing performance, as compared to its role in the manufacturing sector. In order to analyse the impact of market orientation on innovation characteristics and performance, Atuahene-Gima (1996) conducted an empirical research based on 158 manufacturing and 117 service firms in Australia. The results indicate that there is a significant relationship between market orientation and innovation characteristics, i.e., innovation-marketing fit, product advantage, and inter-functional teamwork but not product newness and innovation-technology fit. In addition, the findings of Atuahene-Gima (1996) fail to confirm his hypothesis that a market orientation influences service innovation performance more strongly than it influences product innovation performance. Greenley (1995) researched a relationship between market orientation and performance in the UK and found that the impact of market orientationon performance was moderated by environmental variables. Moreover, the evidence of Greenley (1995) pointed out that in certain market conditions such as highly turbulent markets, low customer power and high technological change, no advantages might occur as a result of market orientation. Hurley\&Hult (1998) tested a sample of 9648 employees from 56 organizations in a large agency of the U.S. federal government in order to incorporate constructs that pertain to innovation in market orientation research. They found that higher levels of innovativeness in the firms' culture were associated with a greater capacity for adaptation and innovation (number of innovations successfully implemented). Additionally, Hurley \&Hult (1998) pointed out that higher levels of innovativeness were associated with cultures that emphasize learning, development, and participative decision making. Todorovic et al. (2013) states that the uniqueness of contemporary business environment implies a need for a flexible, yet integrated management system that will provide strategic, as well as operational excellence in organizations.

Atuahene-Gima\&Ko (2001) analysed market and entrepreneurship orientations and reported the results of a study designed to investigate their effects on a firm's product innovation. These authors classified a sample of 181 firms into four categories labelled as market/entrepreneurship orientation (ME), entrepreneurship orientation (EO), market-oriented (MO), and conservative (CO) firms. Atuahene-Gima\&Ko's (2001) found that there was a significant difference between these groups of firms in terms of subjective and objective measures of performance of new product, as well as in terms of innovation strategies and activities related to market entry timing, product quality, marketing synergy, proficiency of market launch, and management support for innovation. Wiklund\& Shepherd (2003) argue that a firm's entrepreneurial strategic orientation (EO) captures an important aspect of the way a firm is organized. They have found that there is a positive relationship between knowledge-based resources (applicable to discovery and exploitation of opportunities) and firm performance, as well as that this relationship is improved by EO. Anderson et al. (2015) introduced entrepreneurial orientation (EO) reconceptualization by empirical measurement. They presented an empirical illustration of their EO reconceptualization. Covin\&Slevin (1989) investigated the effective strategic responses to environmental hostility among 161 small manufacturing firms and found that in such an environment there was a positive relationship between small firms' performance and their organic structure, entrepreneurial strategic posture, competitive profile characterized by a long-term orientation, high product prices, and concern towards predicting industry trends. Berman et al. (1999) empirically researched the effect of stakeholder management on corporate performance, and they found support for a strategic stakeholder management model but no support for an intrinsic stakeholder commitment model. Based on surveys of U.S. and U.K. firms, Brouthers et al. (2015) found that international performance of SMEs depended on entrepreneurial orientation (EO) and the type of alliance (research or marketing). Omerbegovic-Bijelovic et al. (2016) surveyed entrepreneurship in the public sector of Serbia. They found that it was necessary to stimulate the development of the entrepreneurship concept in the public sector, primarily by further informing management and employees of the public sector about the potentials of entrepreneurship, and also educating them to use the possibilities and opportunities for the application of this concept (OmerbegovicBijelovic et al., 2016).

However, Zack (1999) claims that knowledge is considered the strategically most important resource and that learning the strategically most important capability for business organizations. He thinks that many managers intuitively believe that strategic advantage can come from knowing more than competitors although they are unable to explicitly articulate the link between knowledge and strategy. Zack (1999) provides a framework for making that link and for assessing an organization's competitive position regarding its intellectual resources and capabilities. Calantone et al. (2002) studied the components of learning 
orientation using data from a broad spectrum of US industries. They examined the effect of learning orientation on firm innovativeness, which in turn affects firm performance.

Veselinova\&Samonikov (2012) analysed the most important factors for SMEs' performance, survival and growth in the EU. They considered what determined the potential failure of young companies to innovate and grow. The results by Veselinova\&Samonikov (2012) showed that the age of the firm (which reflects its reputation) was important to the degree to which the firm felt financially constrained. Veselinova\&Samonikov (2012) pointed out that the ability of SMEs to grow depended highly on their potential to invest in restructuring, innovation and qualification. In their attempt to determine the most important financing obstacles for SMEs in Serbia, Eric et al. (2012) carried out a survey among 600 domestic SMEs. On the basis of the survey results, the authors pointed out that only $39 \%$ of SMEs recognized that using strategic orientation when deciding on how to acquire necessary financial resources were highly associated with improved financial performance.

Gatignon\&Xuereb (1997) found that developing superior innovations required that a firm should have a strong technological orientation. In addition, they found that when performing in high-growth markets, competitive orientated firms developed innovations at lower costs, when performing in markets characterized by relatively uncertain demand, consumer-and technology-oriented firms achieved better preforming products and better market innovations thus making superior performances, and that competitive orientation lead to better market innovations in markets with relatively certain demand; also, it was less emphasized in highly uncertain markets. Milutinovicet al. (2015) analysed a concept of strategic innovation given the impact it has on competitiveness, creation of growth strategies, new product categories and business models, as well as on changing the rules of the game on the existing market. Starting from the strategic positioning map, Milutinovic et al. (2015) give some of the possible answers to the question of how SMEs in Serbia can improve their business, i.e., how the National Innovation System (NIS) can influence SMEs in terms of increasing business success. Milic (2013) presented strategic implications of innovation management in the time of economic crisis. Milic (2013) discussed whether and how managers should implement innovation management strategies, in order to set up a strong base and precondition for future business growth, after the crisis is over, but also during the crisis itself.

\section{Theoretical Analysis of Competitive Advantage}

There is a large body of literature and a significant number of extensive research on the subject of gaining competitive advantage. In this field, the work of Porter $(1980,1985,2007)$ has been recognized as the most significant since he provided the most complete conceptual framework for the formulation of competitive strategies. Otherwise, Keskin (2006) states that: "Innovation is the name of the game for competition...". Furthermore, he explains that increased competition, ceaseless turbulence, change and uncertainty have forced organizations to embrace innovation as an integral part of their corporate strategy (Keskin, 2006). In order to remain competitive, firms must continuously develop and adapt their business models (Wirtz et al., 2010). Additionally, Milutinovic et al. (2015) stated that if companies want to be successful they have to discover and exploit new strategic positions that emerge from time to time as industry evolves.

According to Porter (2007), competitive advantage comes from the ability of a company to create value for its buyers which is higher than the costs of creating it. Value is what buyers are willing to pay and it stems from offering lower prices than competitors for equivalent benefit or providing unique benefit which largely neutralizes its higher price (Porter, 2007, p. 20). Coulter (2010) states that competitive advantage requires that an organization should either have something that others do not, do something better than others, or do something that other organizations are not capable of. It is the essence of strategic management (Coulter, 2010 , p. 41). Strategic management is a process that consists of analysis, decisions and actions that an organization undertakes to provide and maintain a competitive advantage (Dess et al., 2007, p. 9). Evidence shows that small-scale organizations often lack strategic orientation. Due to a lack of knowledge on strategic management techniques, lack of appropriate skills, uncertainty and being mainly focused on operating activities, the managers/owners of small-scaled enterprises often avoid long-term planning (Farhad\&Karami, 2003).

The fact that small organizations are not minimized copies of large systems leads to the conclusion that small-sized enterprises cannot use the same strategic solutions as their larger counterparts do. The 
differences between small and large organizations can be seen not only in their size, but also in terms of organizational structure, management style, their impact on the environment. Along with the growth and development of enterprises, i.e., the transformation from small to medium-sized enterprises, a change in the nature of management problems occur, as well as knowledge and skills necessary for their solving. The professionalization of management by hiring highly educated and skilled managers is the most significant change following the growth of an organization (Paunovic, 2012). As an enterprise becomes large and diversified it begins to reap the benefits related to its size (effects of economies of scale, strategic orientation, access to finance, etc.). On the other hand, many new problems occur which require appropriate strategic solutions. The main problem is how to provide synergistic effects based on the size and dispersion of activities (Todorovic, 2003).

Based upon all previously stated, it can be concluded that small business operations are to a large extent determined by internal factors, particularly knowledge and skills of their managers/owners. Given the fact that small business owners are also the managers, their level of motivation for operational efficiency is higher than that of managers of large companies (Paunovic, 2012). The significance of the role of human factor in creating competitive distinctiveness was recognized by Stoner (1987). According to Stoner (1987), the key distinctive competencies of small businesses are to be found in experience, knowledge and skills of their managers.

In organizations that use a simple organizational structure, the owner/manager is engaged in many different roles, approves every decision and controls all activities (Dess et al., 2007, p. 357). Dependence on knowledge, capabilities, professional and personal characteristics of one or very few people can become a serious shortage of small businesses (Paunovic, 2012).

Given the fact that the essence of strategic management refers to creating and maintaining competitive advantage, SMEs need to be strategically directed and guided. However, due to certain specifics, the process of strategic planning in small organizations should be less formalized than it is the case in larger ones (Callahan\&Cassar, 1995). According to Coulter (2010), even if small organizations attempted to transfer the practice of large business systems, their key values, and particularly their flexibility, would be at risk. Consequently, strategic management in smaller enterprises must be less formal, more flexible and primarily oriented towards action (Coulter, 2010, p. 316). Furthermore, Coulter (2010) believes that strategic choice is the same for small and large organizations, although small ones face limitations as to what activities they can engage in, and to what extent. Coutler (2010) also states that, when formulating a strategy, smaller organizations can implement the same strategic directions (namely, growth, stability, recovery) as large systems do but under particular limitations referring to the choice of strategic alternatives within the selected directions. Most small organizations will decide to implement a concentration growth strategy since other strategic options (diversification, vertical integration, horizontal integration, etc.) require significant investment. Lazarevic-Moravcevic et al. (2015) find that growth strategy is a dominant strategic orientation of business managers/owners in Serbia. The research results obtained by these authors show that around $70 \%$ of surveyed managers plan to expand their business in the future. Lazarevic-Moravcevic et al. (2015) find that despite many internal and external problems, the Serbian owners/managers are rather optimistic and have a clear vision in what direction they want to develop their businesses.

Human resource management is one of the key strategic issues that small businesses face during their operation. The recruitment, motivation and retention of employees are among the biggest problems of small organizations (Coulter, 2010, p. 319). Small organizations often deal with high employee turnover rates since they lack strategic approach in hiring human resources, and do not have effective systems for employee's motivation and performance monitoring. When implementing the activities of recruitment, selection and human resources development, standard methods which do not require high costs and can be controlled directly by the owner/manager of the company are usually used (Cardon\&Stevens, 2004). The common practice in the selection of candidates is to use more simple and cheap methods and to give priority to the criteria of loyalty to the company (PKS, 2012). Preferring the criteria of loyalty to the company excludes the possibility of hiring employees with the best qualifications and experience.

The main objective of strategic orientation is to create competitive advantage. According to Porter (2007, $\mathrm{p}$. 31), a competitive advantage can be created by cost leadership or differentiation, i.e., by using one of three generic strategies: Cost leadership, Differentiation, and Focus (Porter, 2007, p. 31). The term generic refers to the fact that these strategies can be used in organizations of all types and sizes no matter of the size and type of a particular business sector (Coulter, 2010, p. 211). 
The main objective of the cost leadership strategy is to have the lowest costs in a given industry. Organizations with the lowest cost of operation can establish prices that are lower than the average market prices. Differentiation means directing activities towards achieving superior performance in an important customer area valued by a large chunk of the market (Kotler, 2006). The focus strategy has two variants. In the cost focus a firm seeks a cost advantage in its target segment, and in the differentiation focus a firms seeks a differentiation advantage in its target segment (Porter, 2000, p. 35).

Porter (1985, p. 17) points out that it is desirable for a company to make clear choice about its strategic orientation, i.e., to have a clear attitude on how it wants to be seen by its buyers - as a producer offering cheap and standard products or offering unique products (services). The firm's success on the market is determined by its commitment to make the choice of a generic strategy it will follow (Porter, 1985, p. 17). Ebben\&Johnson (2005) emphasized that small firms which combined the efficiency strategy (low cost) and the flexibility strategy (differentiation) did worse than firms that used only one particular strategy.

The Porter's (1985) opinion had prevailed in the scientific community for a long period of time. However, Porter's exclusiveness was questioned by numerous examples of good practice, e.g., McDonalds, Google, Toyota which gained and maintained a competitive advantage by integrating elements of both low cost and differentiation strategies. The advanced technology, i.e., the flexible production system, the just-in-time inventory system, and integrated information systems enabled companies to achieve low costs and develop unique products and services (Coulter, 2010, p. 219).

\section{Methodology of Research}

In order to identify the basic strategic orientation of SMEs regarding the choice of their competitive strategy, a survey was conducted on the sample of 102 enterprises in Serbia, out of which 77 belong to the sector of small and 25 to the sector of medium-sized enterprises. The categories of enterprises were classified according to the number of employees. The category of small enterprises is comprised of economic enitities employing up to 50 people, while the category of medium-sized enterprises includes firms employing between 50 and 250 people. The research sample was created by using a selective approach. Consequently, the sample consisted of enterprises with more than 10 employees, enterprises with positive business result and enterprises identified to have growth and development potential.

The research was conducted on the basis of a survey through the use of an electronic questionnaire. A survey is an important data collection method based on the pre-prepared questionnaire which gives respondents the ability give an answer within the previously prepared range of possible answers. This envisages the option that respondents give answers which are outside the defined range. Given that the questionnaires were filled out by the owners/managers of enterprises, the level of competence of respondents is considered high. As in Draskovic\&Minovic (2013), the survey designed in such way offers the option of being anonymous in the sense of expression, without noting any personal data of surveyed persons.

One of the limitations in this research refers to the small presence of the research sample within the category of middle-sized enterprises. The smaller presence of the sample than it was previously planned is mostly due to the lack of managers' willingness to participate in the survey, as well as to the fact that these enterprises account for a smaller share in the total number of enterprises in the SME sector.

The questions relating to the main characteristics of products/services and the type of innovation implemented by SMEs are set in the questionnaire with the intention to identify the sources of competitive advantage. An innovation classification used in this survey includes product innovations and process innovations. It is assumed that product innovation is associated with the differentiation strategy, while process innovation is associated with the cost leadership strategy as it was stated by Desset al. (2007). Data processing, statistical analysis and numerical expression of the results were carried out by using SPSS software, Microsoft Excel and Google Drive support.

Draskovic and Minovic (2013) stated that the use of survey methods represents a useful combination of research techniques and methods. Susnjic $(1977,1999)$ pointed out that economic research should rely on 
techniques and methods such as survey. This technique is available as a method for collecting reliable scientific information relating to subjective views, opinions and attitudes of value on different social and economic facts and factors. Nevertheless, their range and reliability have certain limitations. The limitations lie primarily in the complexity of the survey content, the selected sample and the impact of pooling errors, which should be kept at the lowest possible level (Susnjic, 1977, 1999), (Draskovic and Minovic, 2013).

\section{Results and Discussion}

Figure 1 presents the response frequency to the survey question in which the respondents were asked to state the basic characteristic of their product (service). The respondents had the possibility to choose between the following two answers:

- A price lower than the competition along with an average product (service) quality

- An extremely high quality with a price higher than the competition

The results indicate that the answers of Serbian SMEs to this question converge. Therefore, $45 \%$ of small business managers believe that a lower price is the main characteristic of their product/service, while more than $30 \%$ believe that it is the high quality. Similarly, approximately $30 \%$ of managers in medium-sized enterprises believe that high quality is the basic characteristic of their product/service, while some $70 \%$ believe that it is the lower price (see Figure 1).

The results show that SMEs generally seek competitive advantage in costs, i.e., they achieve competitive advantage in chosen market segments by using The Cost Focus strategy.

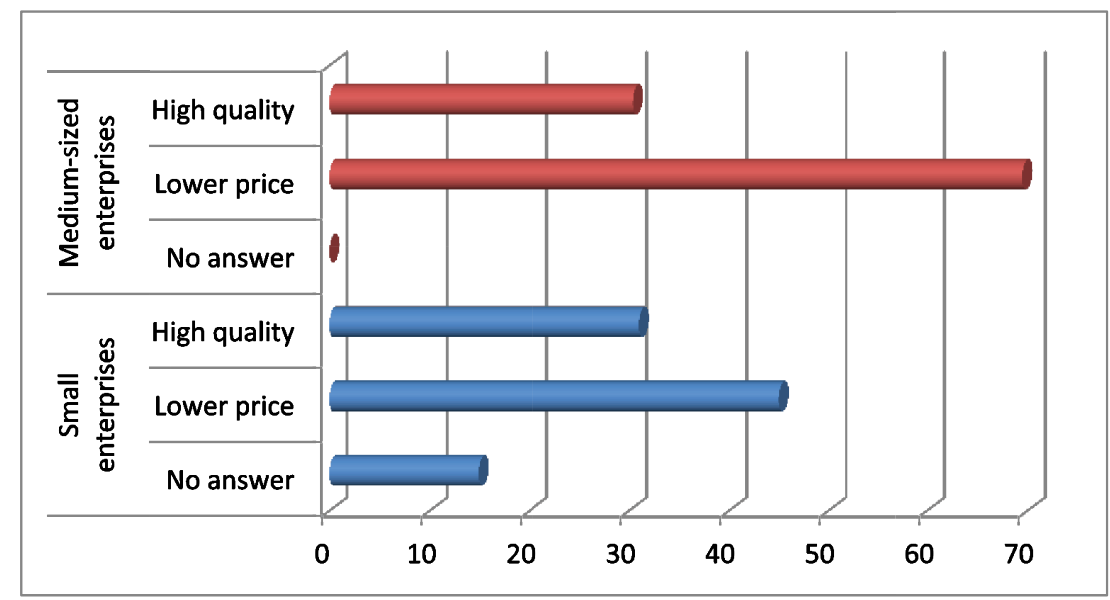

Figure 1: Basic characteristic of product-service Source: Authors' calculation

Also, the survey found that SMEs were entrepreneurial-minded and very active in the field of innovative activities. Speaking of the small enterprise level, approximately $85 \%$ of the sample carried out product or process innovation in the previous couple of years, while in the category of medium-sized enterprises the number amounted to around $96 \%$ of the sample.

The question in which respondents were asked to identify the dominant type of innovation was set in order to determine whether innovation carried out by an enterprise followed the chosen competitive strategy. The research is based on the assumption that enterprises using low cost strategy focus on process innovations, while enterprises using differentiation strategy focus on product innovations.

The results of this empirical research show that product innovation is the dominant type of innovation in small enterprises (more than $50 \%$ of answers). It is more than $30 \%$ and fewer than $50 \%$ of managers in medium-sized enterprises who believe that the dominant type of innovation refers to product innovation and process innovation, respectively (see Figure 2). 


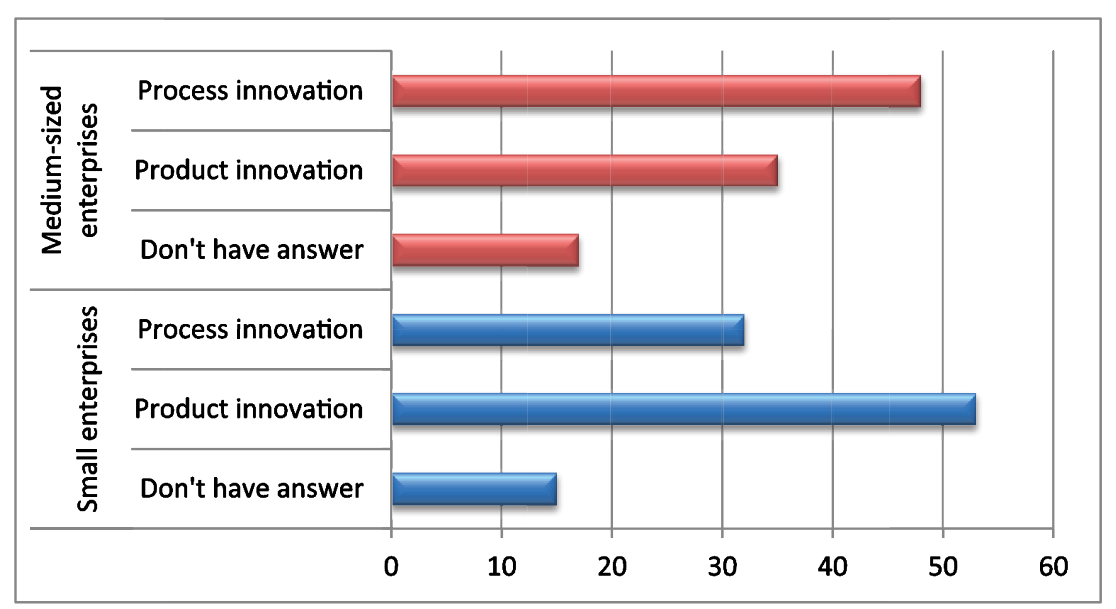

Figure 2.Types of innovation in Small and Medium-sized enterprises Source: Authors' calculation

Empirical results show that innovative activities of medium-sized enterprises are mainly related to processes, i.e., to the improvement of technological processes in order to reduce production cycle time and costs, and that is in line with the cost leadership strategy. On the other hand, activities of small enterprises are focused on product innovations, i.e., on the development and modification of existing products (services) with an aim to improve their quality, design and functionality. Since small enterprises use costs as their main source of competitive advantage, while their innovative activities are mainly related to product differentiation, it can be concluded that innovative activities of enterprises do not follow their basic strategic orientation, i.e., small enterprises attempt to achieve their competitive advantage by combining elements of both cost and differentiation strategies.

The research results show that the first hypothesis which stated that SMEs in Serbia carry out innovative activities cannot be rejected. Additionally, the second hypothesis based on the claim that the type of innovation corresponds to a competitive strategy can be confirmed in case of middle-sized enterprises, while in case of small enterprises it cannot be rejected under the assumption that they combine elements of both cost and differentiation strategies which is known as integrating competitive strategy.

The absence of a strong strategic orientation towards the source of competitive advantage, i.e., the attempts to achieve competitive advantage by combining elements of both the cost focus strategy and the differentiation strategy can result in a scenario defined by Porter (2007) as "stuck in the middle". On the other hand, this phenomenon can be understood as small enterprises' intention to combine elements of the differentiation and cost leadership strategies and to position themselves in the selected market segment either as producers offering medium-quality at below average prices, or offering high-quality at average prices. The risk associated with this strategy is very high. The biggest risk is that the company will fail to provide high value at a particular price or a sufficiently low price for a given set of product attributes. In the former case, the company will be threatened by actions of competitors using the differentiation strategy, and in the latter scenario it will be threatened by competitors using the cost leadership strategy (Kalicanin, 2007). Precisely, this strategy that combines the two sources of competitive advantage - low costs and differentiation might be an optimal solution for the internationalisation of Serbian enterprises, and particularly for their access to the European Union market (Kalicanin, 2007). 


\section{Conslusion}

A competitive advantage is the main objective of all market oriented companies, while strategic orientation constitutes the most important precondition for gaining such an advantage. Due to some specifics concerning small enterprises, as well as characteristics of the business environment for SMEs in Serbia, the growth and development of these organizations should be predominantly based on their internal strengths, and particularly on skills and knowledge of their owners/managers.

In order to create a competitive advantage, SMEs need to be strategically oriented. Taking into account the characteristics of the business environment in Serbia, as well as the problems faced by small businesses, the authors believe that strategic choice of Serbian SMEs regarding the competitive strategy is limited and primarily refers to the Focus strategy. Based on empirical research conducted in the paper, it is concluded that SMEs in Serbia are generally focused on costs as a source of competitive advantage, i.e., they achieve competitive advantage in a selected market segment by offering low price and average quality products/services. Observed in the segment of medium-sized enterprises, the competitiveness strategy is aligned with activities in the field of innovation. In medium-sized enterprises, innovations are mainly related to processes, i.e., to the improvement of technological processes in order to reduce costs. On the other hand, in the segment of small enterprises no compatibility was observed between the competitiveness strategy and the innovative activities. In general, small businesses consider the average quality and a price lower than competition as the main characteristic of their products/services, while the dominant type of innovation refers to the product innovation. In case the prevailing view of the professional community is accepted, the absence of a strong commitment of enterprises regarding the source of competitive advantage i.e., the attempt to achieve the competitive advantage by combining the elements of the cost leadership and the differentiation strategies will result in the "stuck in the middle" position. The authors of the paper also believe that the integrating low cost and differentiation strategies should not be rejected as a possible solution for achieving competitive advantage of small businesses in Serbia. Under certain assumptions (flexible production system, efficient inventory management, intensive use of modern technology, TQM, top-down and bottom-up integration), the strategy combining elements of both low cost and differentiation strategies could be an appropriate solution for SMEs in Serbia. The research results presented in this paper could be beneficial for both scientific and professional community, as well as for economic policy makers in Serbia, particularly considering that the SME sector generates around $30 \%$ of the country's GDP.

The necessary conditions for creating a competitive advantage by implementing an integrating competitive strategy were not discussed in the research conducted in this paper. As a result of that, it is not possible to explicitly state that the attempts of Serbian SMEs to gain competitive advantage by combining elements of the differentiation strategy and the low cost strategy are fully justified.The question whether SMEs really have the ability to adequately implement an integrating strategy or just wander around searching for sources of competitive advantage remains for some future research.

\section{Acknowledgement}

This paper is supported by the Ministry of Education, Science and Technological Development of the Republic of Serbia through research projects 47009 and 179015 . The authors thank the anonymous referees. All remaining errors are the authors' responsibility. 


\section{REFERENCES}

[1] Anderson, B. S., Kreiser, P. M., Kuratko, D. F., Hornsby, J. S., \& Eshima, Y. (2015). Reconceptualizing entrepreneurial orientation. Strategic Management Journal, 36(10), 1579-1596.

[2] Atuahene-Gima, K. (1996). Market orientation and innovation. Journal of business research, 35(2), 93103.

[3] Atuahene-Gima, K., \& Ko, A. (2001). An empirical investigation of the effect of market orientation and entrepreneurship orientation alignment on product innovation. Organization science, 12(1), 54-74.

[4] Berman, S. L., Wicks, A. C., Kotha, S., \& Jones, T. M. (1999). Does stakeholder orientation matter? The relationship between stakeholder management models and firm financial performance. Academy of Management journal, 42(5), 488-506.

[5] Brouthers, K. D., Nakos, G., \&Dimitratos, P. (2015). SME entrepreneurial orientation, international performance, and the moderating role of strategic alliances. Entrepreneurship Theory and Practice, 39(5), $1161-1187$.

[6] Calantone, R. J., Cavusgil, S. T., \& Zhao, Y. (2002). Learning orientation, firm innovation capability, and firm performance. Industrial marketing management,31(6), 515-524.

[7] Cardon, M.S., \& Stevens, C.E. (2004). Managing human resources in small organizations: What do we know? Human Resource Management Review, 14(2), 295-323.

[8] Callahan, T.J. \&Cassar, M.D. (1995). Small Business Owners Assessment of Their Abilities to Perform and Interpret Formal Market Studies. Journal of Small Business Management, 1-9.

[9] Coulter, M. (2010).Strategijskimenadzmentnadelu. Data Status, Beograd.

[10] Covin, J. G., \&Slevin, D. P. (1989). Strategic management of small firms in hostile and benign environments. Strategic management journal, 10(1), 75-87.

[11] Dess, G., Lumpkin, G.,\& Eisner, A. (2007). Strategijskimenadzment. Data Status, Beograd.

[12] Draskovic, B. \&Minovic J. (2013, Decembar). Natural resources and their impact on the development of Serbia.Proceedings from the international conference Economic Sciences on the Crossroad, 4. decembar 2013, Beograd, Institutekonomskihnauka, 503-513.

[13] Ebben, J.J., \& Johnson, A.C. (2005). Efficiency, flexibility, or both? Evidence linking strategy to performance in small firms. Strategic management journal,26(13), 1249-1259.

[14] Eric, D., Beraha, I., Djuricin, S., Kecman, N., Jakisic, B. (2012) Finansiranjemalih i srednjihpreduzeca u Srbiji, Institutekonomskihnauka i PrivrednakomoraSrbije, Beograd, 48-49.

[15] Farhad A.\&Karami, A.(2003). Strategic Management in SME. Thomson Learning, 10.

[16] Gatignon, H., \&Xuereb, J. M. (1997). Strategic orientation of the firm and new product performance. Journal of marketing research, 77-90.

[17] Greenley, G.E. (1995). Market orientation and company performance: empirical evidence from UK companies. British journal of management, 6(1), 1-13.

[18] Han, J.K., Kim, N., \& Srivastava, R.K. (1998). Market orientation and organizational performance: is innovation a missing link? The Journal of marketing, 30-45.

[19] Hurley, R.F., \&Hult, G.T.M. (1998). Innovation, market orientation, and organizational learning: an integration and empirical examination. The Journal of Marketing, 42-54.

[20] Kalicanin, Dj. (2007). O hibridnojgenerickojstrategiji: niskitroskovi i diferenciranjeistovremeno. Ekonomikapreduzeca, 55(7-8), 263-272.

[21] Keskin, H. (2006). Market orientation, learning orientation, and innovation capabilities in SMEs: An extended model. European Journal of innovation management, 9(4), 396-417.

[22] Kotler, P. (2006). Marketing menadzment, Data Status, Beograd.

[23] Lazarevic - Moravcevic M., Pantic O., \&Filimonovic D. (2015). SME sector as a growth factor of employment in Serbia.Proceedings from the international conference New economic policy reforms, Beogradskabankarskaakademija, Beograd.

[24] Lukas, B. A., \& Ferrell, O. C. (2000). The effect of market orientation on product innovation. Journal of the academy of marketing science, 28(2), 239-247.

[25] Milic, T. (2013). Innovation Management in times of economic crisis.Management, 66, 81-88.DOI: 10.7595/management.fon.2013.0001.

[26] Milutinovic, R., Stosic, B., \&Mihic, M. (2015). Concepts and Importance of Strategic Innovation in SMEs: Evidence from Serbia. Management(1820-0222), 77, 35-41.DOI: 10.7595/management.fon.2015.0030.

[27] NARR, 2013. Izvestaj o malim i srednjim preduzecima i preduzetnistvu za 2013. godinu, 8, http://narr.gov.rs/. 
[28] Omerbegovic-Bijelovic, J., Rakicevic, Z., \&Vucinic, A. (2016). Is the Public Sector of Serbia Ready for the Entrepreneurial Concept?. Management (1820-0222), 78, 4551.DOI:10.7595/management.fon.2016.0004.

[29] Paunovic, B. (2012). Preduzetnistvo i upravljanje malim preduzecem. Centar za izdavacku delatnost Ekonomskog fakulteta u Beogradu, 121.

[30] PKS. (2012). PrivrednakomoraSrbije. Analizarezultataistrazivanja o potrebamaprivredezaznanjima i vestinama, http://www.pks.rs/.

[31] Porter, M. (1980). Competitive Strategy. The Free Press, New York, 47.

[32] Porter, M. (1985). Competitive Advantage. The Free Press, New York, 17.

[33] Porter, M. (2007). Konkurentska prednost. Asee, Novi Sad, 31.

[34] Senic, R. (1993).Upravljanjerastom i razvojempreduzeca. Savremena administraciija, Beograd, 129.

[35] Stoner, C. (1987). Distinctive competence and competitive advantage.Journal of Small Business Managemen, 25(2), 33.

[36] Stosic, I., \&Minovic, J. (2014). Benchmarking western Balkan economies.Industrija, 42(1), 149-170.

[37] Susnjic, Dj. (1977). Kritikasocioloskogmetoda, Gradina, Nis, 215-237.

[38] Susnjic, Dj. (1999). Metodologija, Cigoja, Belgrade.

[39] Todorovic, J. (2003).Strategijski i operativnimenadzment.Conzit, Beograd, 301.

[40] Todorovic, M., Mitrovic, Z., \&Bjelica, D. (2013). Measuring project success in project-oriented organizations. Management, 68, 41-48.DOI: 10.7595/management.fon.2013.0019.

[41] Verhees, F. J., \& Meulenberg, M. T. (2004). Market orientation, innovativeness, product innovation, and performance in small firms. Journal of small business management, 42(2), 134-154.

[42] Veselinova, E., \&Samonikov, M. G. (2012). SMEs Inovation and Growth in EU. Management (18200222), 64, 87-94.DOI: 10.7595/management.fon.2012.0022.

[43] WEF. (2016). World Economic Forum, The Global Competitiveness Report 2015-2016. http://www3.weforum.org/docs/gcr/2015-2016/Global_Competitiveness_Report_2015-2016.pdf (retrieved on September 2016).

[44] Wiklund, J., \& Shepherd, D. (2003). Knowledge based resources, entrepreneurial orientation, and the performance of small and medium sized businesses. Strategic management journal, 24(13), 13071314.

[45] Wirtz, B. W., Schilke, O., \& Ullrich, S. (2010). Strategic development of business models: implications of the Web 2.0 for creating value on the internet.Long range planning, 43(2), 272-290.

[46] World Bank. (2016).The World Bank. Doing Business 2016: Measuring Regulatory Quality and Efficiency. Washington, DC: World Bank. DOI: 10.1596/978-1-4648-0667-4. License: Creative Commons Attribution CC BY 3.0

IGO.http://www.doingbusiness.org/ /media/GIAWB/Doing\%20Business/Documents/AnnualReports/English/DB16-Full-Report.pdf Zack, M.H. (1999). Developing a knowledge strategy. California management review, 41(3), 125-145. Zhou, K. Z., Gao, G. Y., Yang, Z., \& Zhou, N. (2005). Developing strategic orientation in China: antecedents and consequences of market and innovation orientations. Journal of business research, 58(8), 1049-1058. 


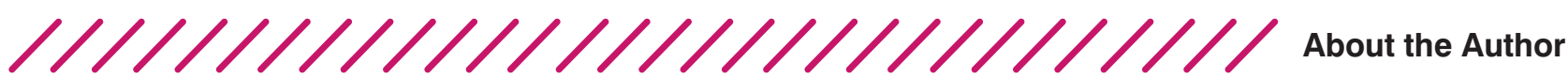

\author{
Jelena Minović \\ Institute of Economic Sciences, Belgrade \\ jelena.minovic@ien.bg.ac.rs; jelena.minovic@gmail.com
}

Jelena Minović, PhD, is a Research Fellow at the Institute of Economic Sciences in Belgrade. She acquired her PhD degree (2012) at the Faculty of Economics, University of Belgrade. Jelena attended the European Business School (EBS University) in Wiesbaden, Germany during her post-doc research stay from May 2013 to August 2013. She participated in many international and national conferences. She published, as author and co-author, a significant number of papers (about 70). Her research interests are: Quantitative Methods and Models in Finance and Economics, Econometrics, Time Series Analysis, Financial Economics and Financial Markets. Her articles have been published in various international journals, such as Applied Economics, Economic Research, Panoeconomicus, Engineering Economics, International Journal of Engineering Education, Economic Annals, Theoretical and Applied Economics, and others.

\section{Marija Lazarević - Moravčević Belgrade Banking Academy marija.lazarevic@bba.edu.rs}

Marija Lazarević - Moravčević, PhD, is an Assistant Professor at the Department of Business Economics and Management, Belgrade Banking Academy - Faculty for Banking, Insurance and Finance, the Union University, Belgrade, Serbia. She acquired her PhD degree (2013) at the Faculty for Banking, Insurance and Finance, the Union University. She earned her postgraduate degree (2005) and undergraduate degree (1999) at the Faculty of Economics, University of Belgrade. She worked at the Institute

of Economic Sciences in Belgrade from 2002 to 2009, where she was engaged in projects financed by the Ministry of Science. Marija participated in many national and international conferences. Her research interests are: Strategic Management, Small and Medium-sized Enterprises and Human Resource Management.
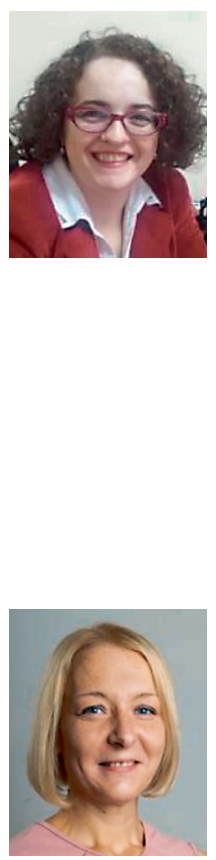

\section{Isidora Beraha \\ Institute of Economic Sciences, Belgrade isidora.beraha@ien.bg.ac.rs;}

Isidora Beraha, $\mathrm{PhD}$, is a Research Associate at the Institute of Economic Sciences in

Belgrade. She acquired her PhD degree (2016) at the Faculty of Entrepreneurial Business, Union-Nikola Tesla University. She earned her postgraduate degree (2010) and undergraduate degree (2005) at the Faculty of Economics, University of Belgrade. From

September 1999 to June 2000 she attended One Year Academic Programme at the Hebrew University of Jerusalem, Rothberg International School, Department for

undergraduate studies, Israel. Isidora participated at a large number of national and international conferences. She published, as an author and co-author, two monographs and a significant number of scientific papers. Her field of research includes: Organization and Management, Small and Medium-sized Enterprises and Entrepreneurship, Clusters. Since 2010, Isidora has been a member of the Entrepreneurship Research and Education Network of Central European Universities - ERENET.

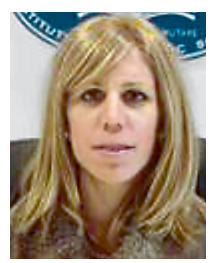

